\title{
Application of atomic absorption spectroscopy for the analysis of chemical composition of Brassica rapa
}

\author{
(C) Olga V. Eliseeva, ${ }^{1}{ }^{+}{ }^{+}$Alexander F. Eliseev, ${ }^{2}$ and Sergey L. Belopukhov ${ }^{1}$ \\ ${ }^{1}$ Chemistry Department. ${ }^{2}$ Olericulture Department. Russian Timiryazev State Agrarian University. \\ Timiryazevskaya St., 49. Moscow, 127434.Russia.Phone: +7 (499)976-16-28. E-mail: elysol11@yandex.ru
}

*Supervising author; ${ }^{+}$Corresponding author

Keywords: atomic absorption spectroscopy, turnip, chemical composition.

\begin{abstract}
This paper presents the study of the chemical composition of Petrovskaya variety of turnip after the non-root treatment of vegetating plants with the solution of trivalent chromium. The treatment has been performed with the solutions of chromic potassium sulphate with chromium concentrations of $0.002 \%$ and $0.005 \%$. The experiment has been conducted according to the following scheme: 1 . NPK (background) control version; 2 . NPK $+\mathrm{HO}$ Cr $0.002 \%$; 3 . NPK $+\mathrm{HO}$ Cr $0.005 \%$. Nitroammophoska was used as the background macro fertiliser during the sowing at the rate of $30 \mathrm{~g} / \mathrm{m}^{2}$. In the control versions plants have been treated with the distilled water. The content of chromium in root vegetables has been assessed using the method of atomic absorption spectroscopy. It is shown that after the treatment with the solution of chromic potassium sulphate the average content of chromium in root vegetables increased by $31.3 \%$ in NPK $+\mathrm{Cr}$ $0.002 \%$ version and by $55.6 \%$ in NPK + Cr $0.005 \%$ version in comparison with the control version. At the chromium concentration of $0.002 \%$ the content of dry matter in turnip remained at the level of control version, the content of dry soluble matters and ascorbic acid decreased down to $5.9 \%$ and $28.60 \mathrm{mg} / 100 \mathrm{~g}$, the level of nitrates in root vegetables increased up to $286.0 \mathrm{mg} / \mathrm{kg}$ of wet mass. At the chromium concentration of $0.005 \%$ the content of dry matter in turnip decreased down to $10.4 \%$, the content of dry soluble matters increased up to $7.3 \%$, the content of ascorbic acid and nitrates decreased down to $27.81 \mathrm{mg} / 100 \mathrm{~g}$ and 210.2 $\mathrm{mg} / \mathrm{kg}$ of wet mass, respectively.
\end{abstract}

\section{References}

[1] V.V. Ageev. Root Treatment of Agricultural Plants. Stavrop. GSKhA. Stavropol. 1996. 134p. (russian)

[2] S.L. Belopukhov, I.I. Dmitrievskaya, O.V. Eliseeva, A.V. Zhevnerov. Instrumental Methods of Agrosphere Objects Exploration: textbook. Moscow: Prospekt. 2019. 160p. (russian)

[3] L.P. Vydrova, L.A. Vorobyova, P.G. Korobeynikova. Valence State of Chromium in Soil. MSU Bulletin. Vol.17. Soil Science. 1990. P.30. (russian)

[4] O.K. Dobrolyubskiy, V.G. Strakhov. Influence of Chromium, Molybdenum, Wolfram on pigment content, photosynthesis and productivity of the grape plant. Agrochemistry. 1983. Vol.3. P.96-102. (russian)

[5] O.V. Eliseeva, and A.F. Eliseev. Foliar treatment of radish plants (Raphanus sativus) chromium potassium alum as a way for obtaining chromium-rich products. Butlerov Communications. 2012. Vol.30. No.4. P.153-156. ROI: jbc-02/12-30-4-154

[6] V.T. Kurkaev, A.H. Sheudzen. Agrochemistry. Maikop: GURIPP “Adygeya”. 2000. 552p. (russian)

[7] A.A. Lapin, S.D. Borisova, M.L. Calayda, and V.N. Zelenkov. Biochemical examination of leaf lettuce, grown in aquaponics. Butlerov Communications. 2019. Vol.59. No.8. P.132-139. DOI: 10.37952/ROI-jbc01/19-59-8-132

[8] N.P. Larionova, V.A. Sidorova. Influence of Soil Conditions on the Phytotoxicity of Chromium. Agrochemistry. 2005. No.20. P.82-87. (russian)

[9] V.A. Litvinskiy, E.A. Grishina, V.V. Nosikov, and S.L. Belopukhov. Application of ICP-AES technique for determination of zinc in plants and plant products. Butlerov Communications. 2018. Vol.54. No.4. P.140-148. DOI: 10.37952/ROI-jbc-01/18-54-4-140

[10] M.Y. Lovkova, N.G. Buzuk, S.M. Sokolova et al. Medicinal Plants - Concentrators of Chromium. The Role of Chromium in the Metabolism of Alkaloids. RAS Bulletin. Biological series. 1996. No.5. P. 552564. (russian) 
APPLICATION OF ATOMIC ABSORPTION SPECTROSCOPY FOR THE ANALYSIS OF CHEMICAL ...

[11] N.A. Protasova. Heavy Metals in Black Soils and Cultivated Plants of the Voronezh Region. Agrochemistry. 2005. No.2. P.80-86. (russian)

[12] G.P. Chupakhina. The System of Ascorbic Acid of Plants: Monograph. Kaliningrad University. Kaliningrad. 1997. 120p. (russian)

[13] A.H. Sheudzen. Biogeochemistry. Maikop: GURIPP “Adygeya”. 2003. 1028p. (russian)

[14] S. Samantary, P. Das. Accumulation and distribution of chromium, nickel and iron in the mungbean plant. Fresnius Environmental Bull. 1997. No.6. P.633-641. 